\title{
Toxicity and Bioaccumulation of Hexavalent Chromium in Green Paramecium, Paramecium bursaria
}

\author{
M. Golam Mortuza, Toshiyuki Takahashi, Tatsuya Ueki, Toshikazu Kosaka, \\ Hitoshi Michibata, and Hiroshi Hosoya*
}

Department of Biological Science, Graduate School of Science, Hiroshima University, 1-3-1, Kagamiyama, Higashi-Hiroshima, Hiroshima 739-8526, Japan

(Received July 27, 2005; Accepted August 1, 2005)

\begin{abstract}
The effects of hexavalent chromium on the cell growth of green paramecium, Paramecium bursaria (P. bursaria), were investigated in this study. Two strains (MB-1 and $\mathrm{F}_{1}$ generation) of $P$. bursaria were incubated in lettuce media supplemented with different concentrations of potassium dichromate under light (L) L (24 hr light), L dark (LD) (12 hr light : $12 \mathrm{hr}$ dark) and DD (24 hr dark) conditions, and the $\mathrm{IC}_{50}$ values were obtained. The $\mathrm{IC}_{50} 7$-day value showed that the toxicity of potassium dichromate was light-sensitive in both strains of $P$. bursaria. The results of the toxic effect of chromium on the cell shape of $P$. bursaria (BWK-4) showed that the body ratio of $P$. bursaria increased, even if the cells were incubated for $24 \mathrm{hr}$ with $0.5 \mu \mathrm{M}$ potassium dichromate solution, indicating that the cell shape of $P$. bursaria is very sensitive to potassium dichromate. The average amount of chromium accumulated in green paramecium ranged from 1.72 to $15.5 \mathrm{pg} \mathrm{Cr} / \mathrm{cell}$ in a time- and concentration-dependent manner. This finding indicates the possibility of the use of $P$. bursaria as a biomonitor and bioaccumulator for chromium contaminants in aquatic environments. The experiment with electrical stimuli into the culture of $P$. bursaria indicated that cells accumulated at the negative electrode, suggesting that $P$. bursaria carried a positive charge. Thus, because the positive charge does not cause any significant absorption of chromium into the cells, $P$. bursaria may develop a variety of mechanisms for chromium accumulation in the cell. Further research studies are required to elucidate the mechanism of chromium uptake in P. bursaria.
\end{abstract}

Key words — toxicity, bioaccumulation, chromium, $\mathrm{IC}_{50}$, Paramecium bursaria

\section{INTRODUCTION}

The increasing trend towards combining industrial and municipal wastes for treatment in sewage plants increases the possibility of contamination of the influent by metal ions. Because microorganisms are key components for the decomposition of organic materials, the effect of metal toxicity on microorganisms has received attention in recent years. ${ }^{1)}$ It is well-known that heavy metals are toxic to most microorganisms at certain concentrations and often cause serious damage in biological waste treatment plants. It has been suggested that the heavy metal concentration produced a certain level of mortality

\footnotetext{
*To whom correspondence should be addressed: Department of Biological Science, Graduate School of Science, Hiroshima University, 1-3-1, Kagamiyama, Higashi-Hiroshima, Hiroshima 739-8526, Japan. Tel.: +81-82-424-7443; Fax: +81-82-4240734; E-mail: hhosoya@hiroshima-u.ac.jp
}

in the culture and visible behavioral changes in the cells, particularly slower movement compared to control. ${ }^{2)}$ However, the mechanisms of their toxic effects are not well elucidated.

In natural water, chromium exists in its two environmentally important oxidation states, chromium (III) and chromium (VI). Chromium (III) is rather benign and is readily adsorbed on soil particles, whereas the chromium (VI), as the most toxic species, is not readily adsorbed. ${ }^{3)}$ Hexavalent chromium compounds are being used in a wide variety of commercial processes; therefore, the unregulated disposal of the chromium-containing effluent in both developing and developed countries has led to the contamination of soil, sediment and surface and ground water. ${ }^{4)}$ In trace amounts, chromium (III) is considered an essential nutrient for numerous organisms, but in higher amounts, it is toxic and mutagenic.5)

The impact of heavy metals on the environment 
and their slow addition through the food chain have promoted many research studies aimed at developing alternative, efficient and low cost systems for wastewater purification. ${ }^{6}$ Various conventional methods for removing dissolved heavy metals, such as chemical precipitation/using ion exchange resins or chemical oxidation/reduction are expensive and may not always be feasible. ${ }^{7)}$ That is why the use of microbial biomass is considered more seriously. $\left.{ }^{8}, 9\right)$

Paramecium bursaria (P. bursaria) is a unicellular organism, which is widely distributed in aquatic environments. One green paramecium possesses several hundred green algae, which are morphologically very similar to algae in the genus Chlorella. Because $P$. bursaria can utilize the photosynthetic products supplied by endosymbiotic algae as nutrients, ${ }^{10)}$ the photosynthetic products enable $P$. bursaria to remain alive under a starvation condition for food organisms. Therefore, the culture of green paramecia is much easier than that of other organisms including other protozoa and mammalian cell lines. With these advantages, the use of paramecia can permit a quicker and more convenient evaluation of the toxicity of various polluting chemicals. ${ }^{11)}$ In addition, ciliates are important components of the aquatic food chain ${ }^{12)}$ and play an essential role in the purification processes of both aerobic and anaerobic biological wastewater treatment systems. ${ }^{13,14)}$ In spite of the important roles played by the ciliated protozoa in the ecology of freshwater ecosystems, little is known about the accumulation efficiency of heavy metals by ciliates. A few papers describing the toxicity and effect of chromium on ciliates have been published. ${ }^{1,14)}$ In this study, the toxicity to and bioaccumulation of chromium (VI) into green paramecium, $P$. bursaria, is analyzed and discussed.

\section{MATERIALS AND METHODS}

Stains and Culture - Three strains of $P$.
bursaria syngen 1, MB-1 (mating type I, Shiga Pre-
fecture, Japan), BWK-4 (mating type IV, Shiga Pre-
fecture, Japan) and $\mathrm{F}_{1}$ generation (immaturity; de-
scribed below) were used in this study. The strains,
MB-1 and BWK-4 were derived from a single cell
collected from Lake Biwa (Shiga Prefecture, Japan).
The $\mathrm{F}_{1}$ generation was newly produced by hybrid-
ization with two stocks, BWK-4 and KN-21. Stock
KN-21 (mating type III) was collected from
Kinokawa River (Wakayama Prefecture, Japan).
Those stains were cultured in lettuce infusion, containing the bacteria Klebsiella pneumoniae (K. pneumoniae) as food, and growing under light (L) dark (D) condition at $23^{\circ} \mathrm{C}$ following the methods previously described by Hosoya. ${ }^{15)}$

Heavy Metal Salt — Potassium dichromate $\left(\mathrm{K}_{2} \mathrm{Cr}_{2} \mathrm{O}_{7}\right)$ (Katayama Chemical, Japan) was used as source of chromium (VI). The stock solution $(10 \mathrm{mM})$ was made and kept in refrigerator at $4{ }^{\circ} \mathrm{C}$ until use.

Determination of Growth Rate and $\mathrm{IC}_{50}$ Value To determine the effect of chromium (VI) on the cell growth of $P$. bursaria, the cells were cultured in 12-well microplates (flat bottom and polystyrene-treated plates, Asahi Glass Co. Ltd., Japan). Each well was filled with $2 \mathrm{ml}$ fresh lettuce infusion containing different concentrations of potassium dichromate $(0-1000 \mu \mathrm{M})$ without $K$. pneumoniae, and each culture was started at an initial density of 1000 cells $/ \mathrm{ml}$. To determine the chronic toxicity, $P$. bursaria (MB-1) cells were incubated for 1, 3, 5 and 7 days under LD condition with $(0.01-100 \mu \mathrm{M})$ or without potassium dichromate. Next, to determine the $\mathrm{IC}_{50} 7$-day value, two stains of $P$. bursaria (MB1 and $F_{1}$ generation) were incubated for 7 days under the LL, LD and DD conditions. After incubation, the number of $P$. bursaria in each well was counted under a binocular microscope (Model CDS, Nikon, Japan). The $\mathrm{IC}_{50}$ values defined as the concentrations of substances required for $50 \%$ inhibition of the proliferation of cells were determined as a parameter for the toxicity of model chemical pollutants.

Cell Shape of $\boldsymbol{P}$. bursaria — To investigate the effect of chromium (VI) on the cell shape of $P$. bursaria, the BWK-4 strain was cultured in lettuce infusion with different concentrations $(0-3 \mu \mathrm{M})$ of potassium dichromate under $\mathrm{LD}$ condition as previously described. After incubation, the cells were fixed in 10\% formalin and photographs were taken by a Nomarski differential interference contrast (DIC) microscope (Optiphot, Nikon) equipped with a digital camera (COOLPIX 900, Nikon).

Chromium Accumulation by Cells — To quantify the chromium accumulation in the cells, $P$. bursaria $\left(\mathrm{F}_{1}\right.$ generation) was cultured in lettuce media supplemented with potassium dichromate $(0$ $160 \mu \mathrm{M})$ at an initial density of 1000 cells $/ \mathrm{ml}$ and incubated for 3 to 7 days. After incubation, the cell number was counted. The samples with or without cells were filtered by membrane filters $(5 \mu \mathrm{m}$ pore, ADVANTEC, Japan), and the membranes were 
washed 3 times with fresh lettuce infusion to remove the unbound chromium. After drying the filters at room temperature, they were treated overnight with $2 \mathrm{ml}$ of $0.1 \mathrm{~N}$ nitric acid (Sigma-Aldrich, Japan). After centrifugation, an aliquot of the supernatant was used to measure the chromium concentration by an atomic absorption spectroscope (AA-220Z, Varian Inc., Australia), equipped with a GTA-96 graphite tube atomizer and a hollow cathode lamp for chromium detection, according to the manufacturer's standard protocol. Chromium standard solution (Wako Pure Chemical, Japan) was used for calibration.

\section{Response of $P$. bursaria to Electrical Stimuli}

To investigate the mechanism of chromium accumulation in green paramecium, $P$. bursaria (BWK4) was tested with electrical stimuli. The experiments were performed in a flat bottom tissue culture dish (35 mm) (Corning 430588, U.S.A.) containing a lettuce medium with $P$. bursaria. Two electrodes (+/-) were placed into the culture media, and a low current (1.5 volt) was supplied from a dry cell battery to monitor the response of $P$. bursaria to the electrical stimuli.

\section{RESULTS AND DISCUSSION}

\section{Effect of Chromium (VI) on the Cell Growth of $P$. bursaria}

The growth of $P$. bursaria (MB-1) in a lettuce medium supplemented with potassium dichromate is shown in Fig. 1. After 1, 3, 5 and 7 days of incubation, the toxicity of chromium was examined on the basis of cell number. The cell numbers decreased tremendously in the presence of $100 \mu \mathrm{M}$ potassium dichromate within $24 \mathrm{hr}$, indicating that $100 \mu \mathrm{M}$ of potassium dichromate shows acute toxicity to the cells.

The light-dependently promoted toxicity is one of the typical features for reactive oxygen generators such as paraquat, methylene blue, haematoporphyrin and chlorophyll. To investigate the light-dependent toxicity, the two stains of P. bursaria (MB1 and $F_{1}$ generation) were incubated for 7 days under LL, LD and DD conditions. The growth rate was designated as values relative to the number of cells right after initiation of culture. The $\mathrm{IC}_{50} 7$-day values of the MB- 1 and $F_{1}$ generation are very similar under LL and $\mathrm{LD}$ conditions. However, the $\mathrm{IC}_{50}$ 7-day values of both strains under the DD condition

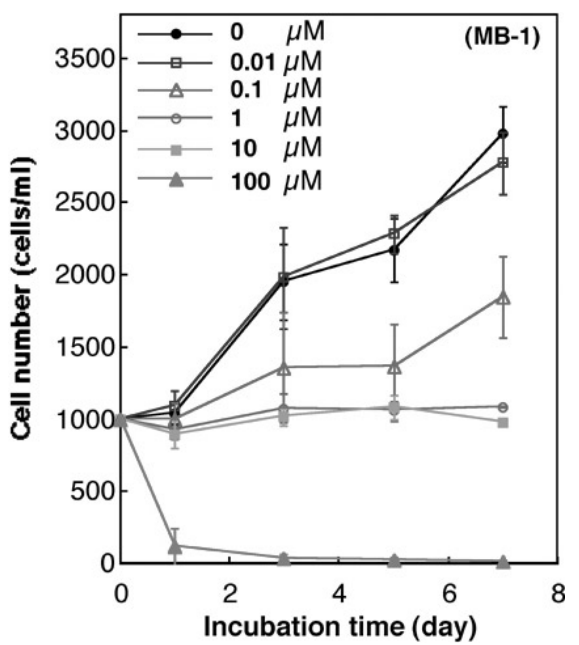

Fig. 1. Effect of Different Concentration of $\mathrm{K}_{2} \mathrm{Cr}_{2} \mathrm{O}_{7}$ on Cell Proliferation of $P$. bursaria (MB-1) under Light and Dark Condition

Showing the cell number after 1,3,5 and 7 days of incubation.

are much higher than those under LL and LD conditions, showing that the toxicity of chromium is lightsensitive in the $P$. bursaria (Fig. 2). Takahashi ${ }^{16)}$ reported the similar observations found in P. bursaria under LL, LD and DD conditions in the presence of different concentrations of paraquat.

Chromium (VI) is the most toxic and mutagenic metal ion in biological systems. Although the toxic effects of chromium on microorganisms and invertebrates have been a topic for researchers over the past few decades, ${ }^{1,14,17,18)}$ less information using $P$. bursaria is available. Tanaka ${ }^{19)}$ reported that the $\mathrm{IC}_{50}$ 5-day value of potassium dichromate ranged from 0.27 to $1.65 \mu \mathrm{M}$ for $P$. bursaria syngen 1 (KSK-103, mating type-IV) under LD condition. This result suggests that the sensitivity to chromium in $P$. bursaria is similar among the different strains.

\section{Effect of Chromium Toxicity on the Cell Shape of P. bursaria}

To evaluate the toxic effect of chromium (VI) on the cell shape, P. bursaria (BWK-4) was cultured in a lettuce medium with $(0.5-3 \mu \mathrm{M})$ or without potassium dichromate. In the control, the body ratio (width/length) of P. bursaria varied from 0.37 to 0.41 . After a 3-day incubation, the body ratio of $P$. bursaria was $0.49,0.50$ and 0.49 in the presence of $0.5,1$ and $3 \mu \mathrm{M}$ potassium dichromate, respectively (Table 1). Even after 7 days of incubation with $20 \mu \mathrm{M}$ potassium dichromate, the body ratio was 0.49 , suggesting that an incubation longer than 


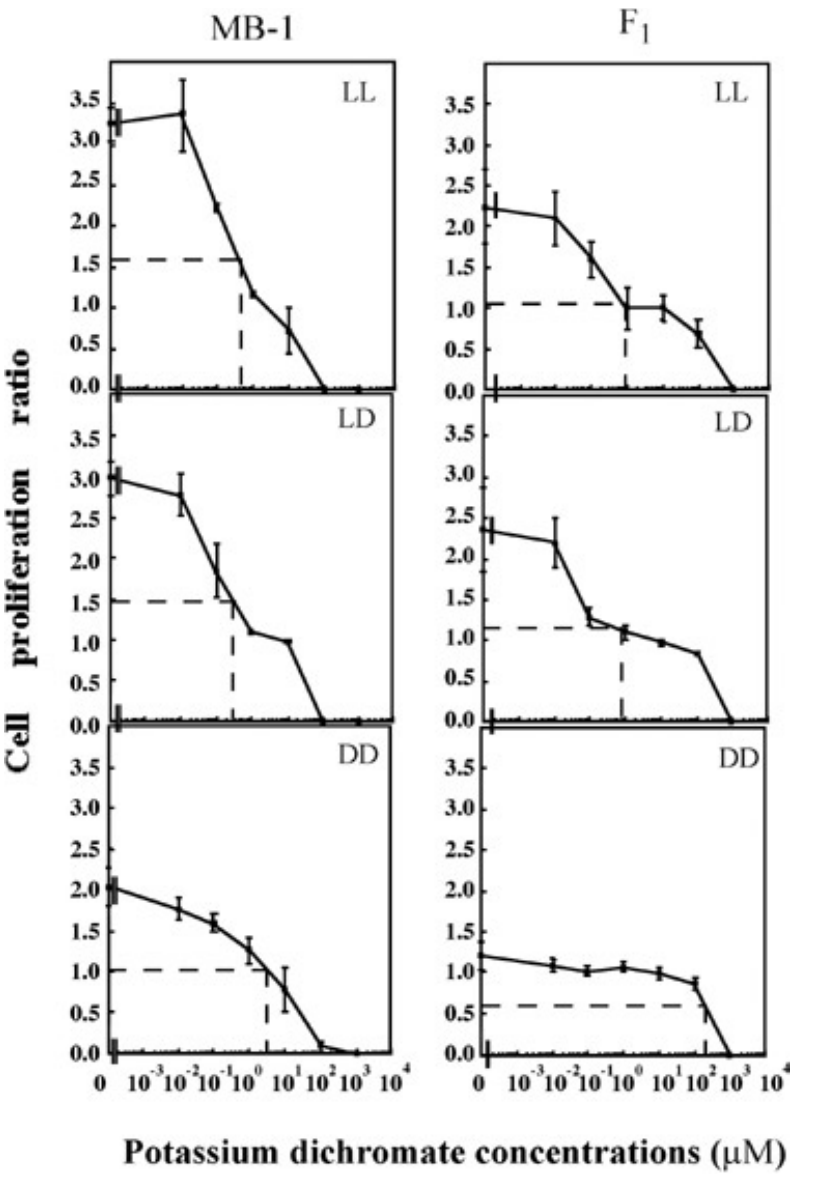

Fig. 2. Estimates of $\mathrm{IC}_{50}$ Values for Population Growth of Two Strains (MB-1 and $\mathrm{F}_{1}$ Generation) of $P$. bursaria after 7 Days Exposure to $\mathrm{K}_{2} \mathrm{Cr}_{2} \mathrm{O}_{7}$ under LL, LD and DD Conditions

3 days and with a concentration of potassium dichromate higher than $3 \mu \mathrm{M}$ caused no more significant changes in the cell shape of $P$. bursaria (data not shown). The cell shape may depend on the cytoskeletal structures in $P$. bursaria. Several investigations revealed that heavy metals caused several changes in the organization of microtubules, which is one of the major cytoskeletal structures, such as the formation of numerous shorter microtubules. ${ }^{20)}$ Gennari $^{21)}$ observed that cadmium ion caused a depolymerization of actin filaments, which is another important cytoskeletal structure. These effects of heavy metal ions on cytoskeletal structures, such as shortening of the microtubule length or depolymerization of microfilaments will disturb the shape of P. bursaria. Chromium (VI) ion may affect the microtubules or microfilaments of $P$. bursaria. More research studies are required to elucidate the mechanisms of the chromium ion effects on the microtu- bules or microfilaments of a $P$. bursaria cell.

\section{Bioaccumulation of Chromium in the Symbiotic P. bursaria}

To investigate the toxicity of chromium in a symbiotic paramecium, the chromium accumulation of $P$. bursaria was detected using an atomic absorption spectrophotometer. The results show that $P$. bursaria accumulated chromium and the accumulation depends on the time and the chromium concentration (Table 2).

Ciliates have many advantages as a test organism for investigating environmental pollution. ${ }^{11,13,14,19,22-24)}$ The study of $P$. bursaria and its interaction with chromium may be useful for bioremediation of chromium-contaminated environments. The aim of the study was to determine the ability of $P$. bursaria to accumulate chromium. Data on the bioaccumulation of heavy metals by invertebrates are available for lead/cadmium in marine protozoan communities, ${ }^{25)} \mathrm{lead} / \mathrm{cadmium} /$ copper/zinc in terrestrial invertebrates ${ }^{26)}$ and organotin in Artemia franciscana. ${ }^{17)}$ However, no data for chromium accumulation by ciliates have been reported. The amount of chromium in the body of green paramecium ( $8.35 \mathrm{pg} \mathrm{Cr} /$ cell) in the presence of $80 \mu \mathrm{M}$ $(8.3 \mathrm{mg} / \mathrm{l})$ potassium dichromate is compared with those for other invertebrates with other metals. In the present study, the chromium accumulation in $P$. bursaria is compared to $2.25 \mathrm{ng}$ Sn/animal accumulated by Artemia franciscana in the presence of $10 \mathrm{mg} / \mathrm{l}$ trimethyltin chloride. ${ }^{17)}$ To evaluate these data, the approximate volume of both animals was calculated and the volume of metal amount $/ \mathrm{m}^{3}$ was obtained. In the present study, the average length of P. bursaria is 115 with $46 \mu \mathrm{m}$ in diameter (Table 1). Abatzopoulos $^{27)}$ reported about the average length and diameter of Artemia franciscana are 10 and $4 \mathrm{~mm}$, respectively. The approximate amount of metal per volume for artemia and paramecium was calculated to be $1.8 \times 10^{10} \mathrm{pg} \mathrm{Sn} / \mathrm{m}^{3}$ and $4.4 \times 10^{13} \mathrm{pg}$ $\mathrm{Cr} / \mathrm{m}^{3}$, respectively. This suggests that the ability for accumulation of chromium in $P$. bursaria is significantly higher than that for tin in artemia. These results indicate that $P$. bursaria may be used as an active bioaccumulator for other heavy metals. The present work suggested that the potential of the symbiotic P. bursaria for the accumulation of chromium (VI) indicates its utility as a bioaccumulator and biomonitor of chromium contamination in freshwater environments. 
Table 1. Length, Width and Body Ratio of P. bursaria (BWK-4)

\begin{tabular}{|c|c|c|c|c|c|c|}
\hline \multirow[t]{3}{*}{ Day } & \multicolumn{6}{|c|}{$\mathrm{K}_{2} \mathrm{Cr}_{2} \mathrm{O}_{7}$ concentration $(\mu \mathrm{M})$} \\
\hline & \multicolumn{3}{|c|}{ Control (0) } & \multicolumn{3}{|c|}{0.5} \\
\hline & Length $(\mu \mathrm{m})$ & Width $(\mu \mathrm{m})$ & Body ratio $^{a)}$ & Length $(\mu \mathrm{m})$ & Width $(\mu \mathrm{m})$ & Body ratio \\
\hline 0 & $\begin{array}{c}113 \pm 9.8 \\
n=35\end{array}$ & $42 \pm 4.0$ & 0.37 & - & - & - \\
\hline 1 & $\begin{array}{c}122 \pm 17.6 \\
n=30\end{array}$ & $50 \pm 9.0$ & 0.41 & $\begin{array}{c}105 \pm 7.3 \\
n=38\end{array}$ & $46 \pm 3.6$ & 0.44 \\
\hline 2 & $\begin{array}{c}109 \pm 7.8 \\
n=34\end{array}$ & $44 \pm 4.0$ & 0.40 & $\begin{array}{c}108 \pm 11.3 \\
n=36\end{array}$ & $51 \pm 5.1$ & 0.47 \\
\hline 3 & $\begin{array}{c}115 \pm 9.5 \\
n=32\end{array}$ & $47 \pm 5.4$ & 0.41 & $\begin{array}{c}101 \pm 10.2 \\
n=34\end{array}$ & $49 \pm 5.2$ & 0.49 \\
\hline Average & 115 & 46 & & & & \\
\hline \multirow[t]{3}{*}{ Day } & \multicolumn{6}{|c|}{$\mathrm{K}_{2} \mathrm{Cr}_{2} \mathrm{O}_{7}$ concentration $(\mu \mathrm{M})$} \\
\hline & & 1 & & & 3 & \\
\hline & Length $(\mu \mathrm{m})$ & Width $(\mu \mathrm{m})$ & Body ratio & Length $(\mu \mathrm{m})$ & Width $(\mu \mathrm{m})$ & Body ratio \\
\hline 0 & - & - & - & - & - & - \\
\hline 1 & $\begin{array}{c}103 \pm 10.0 \\
n=38\end{array}$ & $49 \pm 5.0$ & 0.48 & $\begin{array}{c}102 \pm 7.3 \\
n=34\end{array}$ & $47 \pm 3.5$ & 0.46 \\
\hline 2 & $\begin{array}{c}105 \pm 8.1 \\
n=40\end{array}$ & $51 \pm 5.0$ & 0.49 & $\begin{array}{c}103 \pm 8.9 \\
n=36\end{array}$ & $49 \pm 4.2$ & 0.48 \\
\hline 3 & $\begin{array}{c}106 \pm 10.3 \\
n=34\end{array}$ & $53 \pm 4.1$ & 0.50 & $\begin{array}{c}100 \pm 7.3 \\
n=34\end{array}$ & $49 \pm 4.1$ & 0.49 \\
\hline
\end{tabular}

a) Body ratio calculated as width/length.

Table 2. Chromium Accumulation by P. bursaria ( $\mathrm{F}_{1}$ Generation) in Lettuce Media Supplemented with Potassium Dichromate

\begin{tabular}{ccccc}
\hline \hline $\begin{array}{c}\mathrm{K}_{2} \mathrm{Cr}_{2} \mathrm{O}_{7} \\
\text { concentrations }(\mu \mathrm{M})\end{array}$ & $\begin{array}{c}\text { Cell number after } \\
\left.\text { incubation (cells/ml })^{a}\right)\end{array}$ & $\begin{array}{c}\text { Duration of } \\
\text { incubation (day) }\end{array}$ & $\begin{array}{c}\text { Total amount of } \mathrm{Cr} \\
\text { in the pellet }(\mathrm{ng})^{b}\end{array}$ & $\begin{array}{c}\text { Amount of } \\
\mathrm{Cr} / \mathrm{cell}(\mathrm{pg})\end{array}$ \\
\hline 0 & $1231 \pm 108.3$ & & 0.78 & 0.32 \\
5 & $1181 \pm 71.7$ & 3 & 4.06 & 1.72 \\
10 & $981 \pm 41.9$ & & 5.02 & 2.56 \\
20 & $994 \pm 46.7$ & & 8.42 & 4.24 \\
0 & $2720 \pm 318.9$ & 7 & 0.52 & 0.1 \\
5 & $1419 \pm 182.0$ & & 6.04 & 2.13 \\
10 & $1292 \pm 273.2$ & & 10.4 & 6.04 \\
20 & $1148 \pm 209.9$ & & 14.7 & 0.16 \\
0 & $2742 \pm 343.4$ & 7 & 0.88 & 8.26 \\
40 & $1200 \pm 251.0$ & & 18.8 & 8.35 \\
160 & $1031 \pm 118.2$ & & 17.2 & 15.5 \\
\hline
\end{tabular}

a) 2000 cells in $2 \mathrm{ml}$ of lettuce infusion were incubated without or with various concentrations of chromium. $b$ ) Total amount of $\mathrm{Cr}$ was calculated in the pellet of cells obtained from the total volume $(2 \mathrm{ml})$ of culture.

\section{Response of the P. bursaria to Electrical Stimuli}

To determine the electrical charge in P. bursaria, two electrodes were placed in the paramecium culture medium, and the response of $P$. bursaria to electrical stimuli was monitored. On supplying a low electrical current, the paramecia were swimming towards the negative electrode, and a large number of cells were concentrated around the negative electrode. After removing the electrodes from the culture media, the swarming of $P$. bursaria gradually disappeared from the negative electrode (Fig. 3). The results show that green paramecia carry a positive 


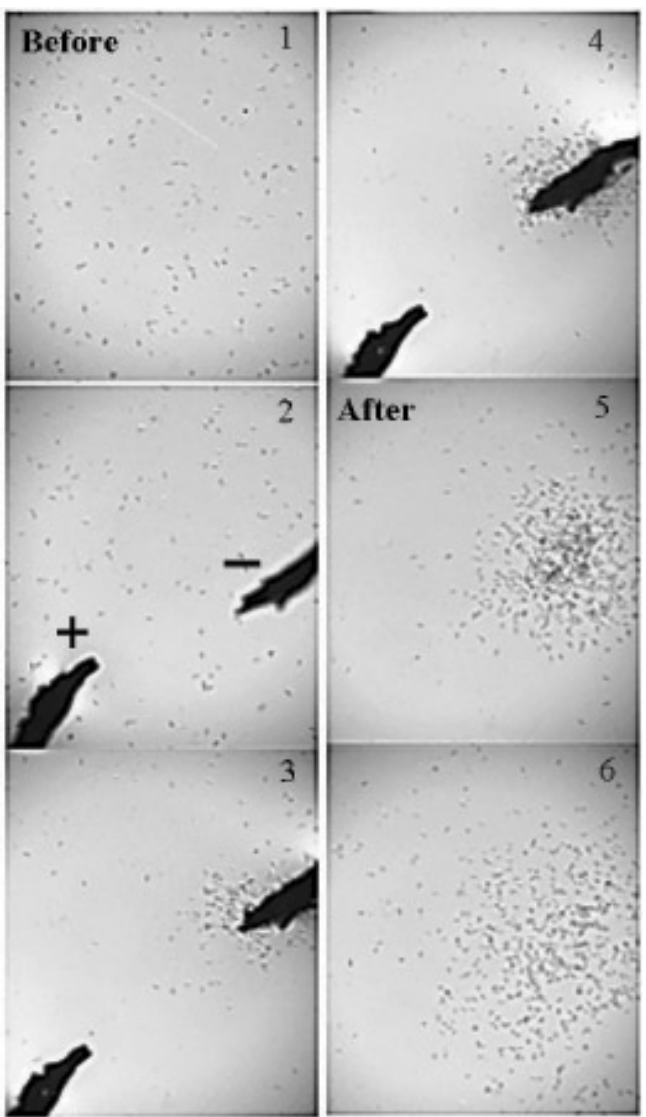

Fig. 3. P. bursaria Shows a Response to Electrical Charge when Two Electrodes (+/-) are Placed in the Paramecium Culture Medium

Panel 1. P. bursaria is normally swimming in the culture media. Panel 2. Two electrodes are placed in the paramecium culture medium. Panels 3 and 4. Paramecia are swimming toward the negative electrode and swarming near the negative electrode end. Panels 5 and 6 . Two electrodes are removed from the paramecium culture medium and the swarming of $P$. bursaria near the negative electrode gradually disappeared.

(+) charge. Wichterman ${ }^{28)}$ reported that the paramecium showed the same charge. Because chromium ion is positively charged, its accumulation in the $P$. bursaria is not caused by electromagnetic interaction, suggesting that the $P$. bursaria may develop a variety of mechanisms for chromium uptake and metabolisms such as the binding of chromium (VI) to DNA or proteins. A metalloproteome is known to be a set of proteins that has metal-binding capacity by being metalloproteins or by having metal-binding sites. A different metalloproteome may exist for each metal. ${ }^{29)}$ Therefore, characterization of metalloproteomes provides information relating to the cellular accumulation of heavy metals. Salnikow ${ }^{30)}$ described that $\mathrm{Cr}$ (III) was directly involved in the formation of DNA-protein complexes in intact cells.
However, information on a $\mathrm{Cr}$ (VI) binding protein has not been published. Future research should be aimed at elucidating the characterization of chromium (VI) binding proteins.

Acknowledgements We thank K. Miyauchi and other members of the laboratory for their helpful discussions and valuable suggestions.

\section{REFERENCES}

1) Stasinakis, A. S., Mamais, D., Thomaidis, N. S. and Lekkas, T. D. (2002) Effect of chromium (VI) on bacterial kinetics of heterotrophic biomass of activated sludge. Water Res., 36, 3341-3349.

2) Martin-Gonzalez, A., Borniquel, S., Diaz, S., Ortega, R. and Gutierrez, J. C. (2005) Ultrastructural alteration in ciliated protozoa under heavy metal exposure. Cell Biol. Int., 29, 119-126.

3) Donmez, G. and Kocberber, N. (2005) Bioaccumulation of hexavalent chromium by enriched microbial cultures obtained from molasses and $\mathrm{NaCl}$ containing media. Process Biochem., 40, 2493-2498.

4) Szulczewski, M. D., Helmke, P. A. and Bleam, W. F. (1997) Comparison of XANES analysis and extractions to determine chromium speciation in contaminated soils. Environ. Sci. Technol., 31, 29542959.

5) Shen, H. and Wang, Y. T. (1993) Characterization of enzymatic reduction of hexavalent chromium by Escherichia coli ATCC 33456. Apppl. Environ. Microbiol., 59, 3771-3777.

6) Wilhelmi, B. S. and Duncan, J. R. (1995) Metal recovery from Saccharomyces cerevisiae biosorption columns. Biotechnol. Lett., 17, 1007-1010.

7) Price, M. S., Classen, J. J. and Payne, G. A. (2001) Aspergillus niger absorbs copper and zinc from swine wastewater. Bioresour Technol., 77, 41-49.

8) Slaveykova, V. I., Wilkinson, K. J., Ceresa, A. and Prestsch, E. (2003) Role of fulvic acid on lead bioaccumulation by Chlorella kesslerii. Environ. Sci. Technol., 37, 1114-1121.

9) Hussein, H., Farag, S., Kandil, K. and Moawad, H. (2005) Tolerance and uptake of heavy metals by Pseudomonads. Process Biochem., 40, 955-961.

10) Weis, D. S. (1979) Correlation of sugar release and Concanavalin A agglutinability with infectivity of symbiotic algae from Paramecium bursaria for aposymbiotic P. bursaria. J. Protozool., 26, 117119.

11) Miyoshi, N., Kawano, T., Tanaka, M., Kadono, T., Kosaka, T., Kunimoto, M., Takahashi, T. and Hosoya, H. (2003) Use of Paramecium species in 
bioassays for environmental risk management: determination of $\mathrm{IC}_{50}$ values for water pollutants. $J$. Health Sci., 49, 429-435.

12) Piccinni, E., Irato, P., Coppelotti, O. and Guidolin, L. (1987) Biochemical and ultrastructural data on Tetrahymena pyriformis treated with copper and cadmium. J. Cell Sci., 88, 283-293.

13) Madoni, P., Esteban, G. and Gorbi, G. (1992) Acute toxicity of cadmium, copper, mercury and zinc to ciliates from activated sludge plants. Bull. Environ. Contam. Toxicol. Environ., 49, 900-905.

14) Madoni, P., Davoli, D., Gorbi, G. and Vescovi, L. (1996) Toxic effect of heavy metals on the activated sludge protozoan community. Water Res., 30, 135141.

15) Hosoya, H., Kimura, K., Matsuda, S., Kitaura, M., Takahashi, T. and Kosaka, T. (1995) Symbiotic algae-free strains of the green Paramecium bursaria produced by herbicide paraquat. Zool. Sci., 12, 807810.

16) Takahashi, T., Yoshii, M., Kosaka, T. and Hosoya, H. (2005) The effect of acrylamide inducing the reduction of nitrobluetetrazolium on the ciliates and human cultured cells. ITE Lett., 6, 50-58.

17) Hadjispyrou, S., Kungolos, A. and Anagnostopoulos, A. (2001) Toxicity, bioaccumulation and interactive effects of organotin, cadmium and chromium on Artemia franciscana. Ecotoxicol. Environ. Saf., 49, 179-186.

18) Yap, C. K., Ismail, A. H., Omar, H. and Tan, S. G. (2004) Toxicities and tolerance of $\mathrm{Cd}, \mathrm{Cu}, \mathrm{Pb}$ and $\mathrm{Zn}$ in a primary producer (Isochrysis galbana) and in a primary consumer (Perna viridis). Environ. Int., 29, 1097-1104.

19) Tanaka, M., Ishizaka, Y., Tosuji, H., Kunimoto, M., Nishihara N., Kadono, T., Kawano, T., Kosaka, T., Hosoya, N. and Hosoya, H. (2005) A new bioassy system for detection of chemical substances in environment using green Paramecia, Paramecium bursaria. In Environmental Chemistry (Lichtfouse, E., Schwarzbauuer, J. and Robert, D., Eds.), SpringerVerlag, Berlin, pp. 495-504.

20) Lin, K. C. and Chou, I. N. (1990) Studies on the mechanisms of $\mathrm{Ni}^{2+}$ induced cell injury: I. Effects of $\mathrm{Ni}^{2+}$ on microtubules. Toxicol. Appl. Pharmacol., 106, 209-221.

21) Gennari, A., Cortese, E., Boveri, M., Casado, J. and Prieto, P. (2003) Sensitive endpoints for evaluating cadmium-induced acute toxicity in LLC-PK1 Cells. Toxicology, 183, 211-220.

22) Abraham, J. V., Butler, R. D. and Sigee, D. C. (1997) Ciliate populations and metals in an activated-sludge plant. Water Res., 31, 1103-1111.

23) Salvado, H., Mas, M., Menendez, S. and Gracia, M. P. (2001) Effects of shock loads of salts on the protozoan communities of activated sludge. Acta Protozool., 40, 177-185.

24) Gutierrez, J. C., Martin-Gonzalez, A., Diaz, S. and Ortega, R. (2003) Ciliates as potential source of cellular and molecular biomarkers/biosensors for heavy metal pollution. Eur. J. Protistol., 39, 461-467.

25) Fernandez-leborans, G. and Olalla, Y. H. (2000) Toxicity and bioaccumulation of lead and cadmium in marine protozoan communities. Ecotoxicol. Environ. Saf., 47, 266-276.

26) Heikens, A., Peijnenburg, W. J. G. M. and Hendriks, A. J. (2001) Bioaccumulation of heavy metals in terrestrial invertebrates. Environ. Pollut., 113, 385393.

27) Abatzopoulos, T. J., Beardmore, J. A., Clegg, J. S. and Sorgeloos, P. (2002) Chapter I. In Artemia basic and applied biology, Kluwer Academ. Pub., pp. 1-37.

28) Wichterman, R. (1986) Chapter 6. Movement, behaviour and motor response. In The biology of Paramecium ( $2^{\text {nd }}$ Eds.), Plenum Press, New York and London, pp. 211-238.

29) She, Y. M., Narindrasorasak, S., Yang, S., Spitale, N., Roberts, E. A. and Bibudhendra, S. (2003) Identification of metal-binding proteins in human hepatoma lines by immobilized metal affinity chromatography and mass spectrometry. Mol. Cell Proteomics., 2, 1306-1318.

30) Salnikow, K., Zhitkovich, A. and Costa, A. (1992) Analysis of the binding of chromium to DNA and protein in vitro and in intact cells. Carcinogenesis, 13, 2341-2346. 